\title{
Complaining Behavior: The effect of different factors on Consumer Complaining Behavior
}

\author{
Anam Manzoor \\ MS Scholar, Department of Management Sciences \\ The Islamia University of Bahawalpur, Pakistan
}

Muhammad Rizwan

Lecturer, Department of Management Sciences,

The Islamia University of Bahawalpur, Pakistan

Email: rizwan.arshad@iub.edu.pk

\section{Mehak Nazir}

MS Scholar, Department of Management Sciences

The Islamia University of Bahawalpur, Pakistan

\section{Nadia Perveen}

MS Scholar, Department of Management Sciences

The Islamia University of Bahawalpur, Pakistan

Accepted: September 13, $2013 \quad$ DOI: 10.5296/jpag.v3i3.6218

\begin{abstract}
Purpose: The aim of this paper is to comprehensively understand the determinants who affect the customer intention to complain to firm through an integrated model and also the effect of those determinants on the complaint intention and the relationship of those intentions with the complaining behavior.

Design/Approach/Methodology: A quantitative research method was used based on self administered questionnaire with a sample size of 171 participants collected by using convenience sample and the results were tested through regression analysis.

Findings/Results: The results shows that the complaining intention and attitude towards complaint have a significant relationship with complaining behavior while prior experience and controllability to complain have an insignificant relationship with complaining behavior. Attitude towards complaint and perceived possibility of success have a significant
\end{abstract}


relationship with intention to complain. The antecedent prior experience has a significant relationship with perceived possibility of success and an insignificant relationship with attitude towards complaint. The variable controllability to complaint has a significant relationship with both perceived possibility of success and attitude towards complaint while Perceived alienation has a significant relationship with perceived possibility of success but insignificant relationship with attitude towards complaint.

Limitations and recommendations: This study is conducted on a small level with small sample size. Due to which there are some insignificant relationships which can be prove as significant relationship if the sample size is large. A limited number of variables are discussed in this article. Other researchers can elaborate other variables affecting complaining behavior e.g. word of mouth, level of dissatisfaction etc.

Keywords: Complaining Behavior, Intention to complain, Attitude towards complain, Perceived possibility of success, Controllability to control, Perceived Alienation, Prior experience

\section{Introduction}

At the present time, companies really show more interest in listening and attending to problems of their customers. According to the recent researches 20 percent of the total losses, if companies have to bear, are contributed from their customer each year, so companies cannot afford to avoid issues of their customers, because researchers have also proved that the cost of attaining a new customer in 5\% more then to retain a customer (Hart, Heskett, and Sasser 1990). So it is very evident that attracting new customers is really an expensive phenomenon then to retaining the old and loyal ones so it's really better for companies to attend to complaints of their customers and try to reduce the turnover of their customer base (Reichheld 1996).

In fact the customers who are not really satisfied with the product or services of the company are now encouraged to convey their dissatisfaction either through any means of communication, they feel comfortable for communicating with company or its representatives,

(it may be over telephone) (Garrett and Meyers, 1996). But in real, it's not the case that all the problems that are communicated to the company, represent the overall average of dissatisfaction of customers, because till now we cannot assume that all the dissatisfied customers may reach to the company and communicate with them through any means of communication (Best and Andreasen, 1977; Day et al., 1981; Hupperts, 2003). In fact, in most of the cases customer facing dissatisfaction, may break its relation with the company to avoid that problem, or may silently wait, supposing that things will get right by time (Hirschman, 1970, p. 38). Even it may be timely or situational decision of the customer to not to communicate his problem, as in case if the customer is in hurry and may prefer not to convey his problem, and move ahead (Jacoby and Jaccard, 1981).

Those complaints which are conveyed to the company are known as friendly complaints as companies have the chance of improving themselves through it (Prim and Pras, 1999). And 
those companies which respond properly to complaints of their customers in fact can reduce the element of being silent or dissatisfaction from their customers (Durvasula, Lyonski and Mehta 2000), make sure to some extent that their customer will come back to them from very next and will not move to any other company (Fornell and Wernerfelt, 1987). So it's a fact that companies really get a chance to decrease the dissatisfaction of their customer and increase their affection with the firm if the handle the complaint in a right manner (Hart, Heskett and Sasser 1990). So it is conveniently stated that complaints are the way to increase the prosperity of the companies (Huang, Huang, \& Wu, 1996).

Additionally in case if the companies doesn't pay attention towards collecting and resolving complaints from their customers, they may have to suffer its harmful consequences, because in extreme cases customers may go towards taking legal actions against company ,or may badly hurt the image of the company through its word of mouth communication (Davidow and Dacin, 1997).so to avoid the destructive consequences and increasing the chances of improvement in their performance as well as profitability companies have to work out to increase the tendency of complaining especially in those customers who feel dissatisfied from them.

But it's a great art to effectively handle the complaints and to alter the dissatisfied state of customer in completely satisfied one, because mishandling the problems of customers may worsen the situation, because it may lead to increase the frustration of the customer and increase the chances negative reaction from the side of consumer (Hoffman \& Chung, 1999; Hart, James, \& Earl, 1990; Mattila, 2001). It means that ineffective handling of the complaint will increase the chances that consumer may leave the company, or spread negative word of mouth communication or may take any legal action against the company. Singh (1988) classified complaining behavior into three categories on the basis of his experiential categorization; these are voice, public actions, and private actions. The first category, i.e. voice refers to any type of communication of the problem directly to the company. The next category i.e. Public action, in contrast doesn't involve any direct communication with the company, it usually refers to making some legal actions against company, or communicating their problem to some influential party, such as publically complaining through media, or taking action against that firm with the help of consumer court (Heung and Lam, 2003).

The third category according to Singh (1988), Private actions represent to the silent actions of the customer, in which he doesn't communicate his problem directly or indirectly to the company instead he silently switch to some other brand, leave to purchase any product of that company, and even spread negative word of mouth against that product and company to his family and friends (Broadbridge and Marshall, 1995; Kim et al., 2003; Tronvoll, 2007). As companies generally are unable to know about these private actions of the company, so they don't get any chance to improve their product and retain their customer so it's the most dangerous kind of reaction from the side of the customer (Heung and Lam, 2003). According to Bearden and Oliver (1985:p. 228) taking actions privately may or may not even affect the attitude of the company, but it may increase the potential customer churn, as the company losses a lot of their present and potential customers due to this sort of reaction. 
According to Gürsoy et al. (2003) individuals of Asian as consumers, really prefer to take action privately, which is proved in his studies and these results are really consistent with previous researches as well. So the main purpose of discussing all these behaviors is to make firms realize that at present time it is really important to give attention to complaints of consumer, and treat them carefully and companies should try to encourage customers to convey their dissatisfactions directly to the company either through any mean so that company may get to know about problems and faults on their side and may have the chance to improve their product or services and retain its potential customers, profitability and prosperity as well. So this research paper focuses on explaining different kinds of complaining behaviors, and those factors which directly or indirectly, may affect the intentions of consumer to convey their problems to the company or not, so in this way companies may be able to increase the tendency to complaints and may get more chances to retain their customers (LiYin Jin, 2010).

Our proposed model suggests that intention towards complain (ITCo) directly affects the consumer complain behavior $(\mathrm{CCBr})$, and complaint intention is effected by the two key attitudinal and perceptual variables (A\&P variables) which are further dependent on three generalized personal factors i.e. consumer alienation $(\mathrm{CAl})$, prior complaint experience (PExp) and controllability towards complaint (CTC) which are said to be the antecedents which affect indirectly to CCI and CCB'r. The A\&P variables which are directly affecting the ITCo are focal point of our model and those variables are perceived possibility of success (PPS) and attitude towards complaint (ATCo) (LiYin Jin, 2010).

\section{Literature review}

\section{a. Consumer complaining behavior}

$\mathrm{CCBr}$ can be explained as reaction of consumer in state of communicating their problem or complaint (Singh and Widing, 1991). According to Crie (2003, p. 61) CCBr is a process which can defined as composition of all the possible responses in sate of dissatisfaction, after purchasing and consuming some product or service. He also explains that $\mathrm{CCBr}$ is not a sudden reaction, but consequence of assessment of process of purchasing and using some product or service of the company. According to Broadbridge and Marshall (1995) CCBr is a unique process when consumer starts assessing his purchase and consumption decision whenever he feels dissatisfied with some particular product till he completely decide that how to respond that dissatisfaction.

According to Jacoby and Jaccard (1981) CCBr as an activity of individual, including the complete process of conveying his feeling of being dissatisfied directly to the company or to any influential party. And as explained before according to Singh (1988) CCBr can be viewed as any response which can easily be categorized as voice response, private or public action.

\section{b. Intention to complaint:}

Intention can be defined as the drive of some individual to show some specific reaction, and can be measured from the amount of time and efforts he is willing to dedicate to perform that action (Ajzen, 1991). The ITCo can be extended from Ajzen's definition, as the willingness 
and drive of consumer to convey his dissatisfaction or complaint to the company (Kim et al., 2003).

According to TPB, Behavioral intention can be treated as function or derivation of individual's own behavior. In other words, complaint behaviors increase with the increase in CCI. In this context, the hypothesis of the study is as stated:

\section{H1: There is a significant relationship between ITCo and CCBr.}

\section{c. Attitude toward complaining}

ATCo can be explained as general reflection or influence of positivity or negativity about conveying the complaint to the company, but it cannot be viewed as any specific or individual experience (Singh and Wilkes, 1996). Attitude plays an important role in deriving the tendency of ITCo and its contribution and significant influence over the intention of consumers to complaint about their dissatisfaction can be supported with the hypothetical framework by Hirschman (1970), in which ITCo is explained as determinant of ATCo along with some other variables. According to Kim et al. (2003) ATCo can also influence the intentions of consumer about complaining or not. Consumer will go towards complaining only if he has any intention like that, and his or her intention can be influenced by positivity or negativity in his attitude about complaining (Rizwan et al., 2013).

Those individuals or consumers who have positive ATCo will go towards communication of their dissatisfaction, otherwise those individuals who perceive complaining as negative behavior means that they have negative ATCo (Keng et al, 1995). It is also explained in TPB, with the increase in positivity of consumer's ATCo, it will automatically tend to increase the motivation of consumer to intend to complaint. According to Richins (1987), consumer's final decision of making complaint or to avoid the communication or being silently leave that company, is directly determined by consumer's belief that what he thinks about complaining and what his attitude is actually towards that. It is also dependent on the attitude of the consumer that with what intention he actually conveys his dissatisfaction to the company, either to get some sort of compensation, return in terms of money, or something else.

The same relationship between ATCo and ITCo is also explained in the previous researches by Keng et al. (1995); Kim et al. (2003); Oh, (2006).

So, on the basis of past researches we can state our hypothesis, which is:

\section{H2: There is a significant relationship between ATCo and ITCo.}

The attitude of the individual may be explained as his personal and subjective belief in the state of dissatisfaction even that what he think about communicating his dissatisfaction to company. Whether he prefer to communicate his dissatisfaction to the company directly or not, and generally he or she thinks positive or negative about complaining and what he or she expect as consequence of complaining either any compensation or returns from the company (Richins, 1987). Some consumers think that is worthy and reasonable to communicate their complaints to the company, and in return obtain some sort of reparation from them and reduce their negative experiences from the next time but some consumers think it worth less 
to convey their complain to the company and may go towards private actions instead (LiYin Jin, 2010).

So Consumers with positive ATCo will express the complaints because it increases the likelihood of showing their behavior in the form of complaining. On basis of this we can hypothesized that

\section{H3: There is a significant relationship between ATCo and CCBr.}

\section{d. Perceived possibility of success}

Perceived possibility of success (PPS) of complaint can be explained as likelihood of successful communication of the complaint in the perception of the customer, and probability that he may get any incentive, repayment, or any kind of excuses from the company, that he is expecting as a compensation of his dissatisfaction he has gone through (Singh, 1990). If the consumer perceive that there is higher probability, that his complaint will be listened and welcomed by the company and they will surely get compensation in return of this discomfort, so there will be increased probability of increasing their intention towards making complaint. On the other hand if individual think that company or firm is neither concerned with their dissatisfaction or their problems, and they will not get any kind of compensation in return of efforts they will make in communicating their problem to the company, so they will prefer to keep silent, and silently leave using that product or service, or in severe conditions may leave that company. Earlier studies also support that idea that with the increase in PPS of complaint, there is increased chances that consumer will intend to complaint to the company directly (Singh, 1989; Richins, 1987).

So on the basis of the previous researches, we can hypothesize that,

\section{H4: There is a significant relationship between PPS and ITCo.}

\section{e. Prior Experience}

According to Tronvoll, (2008b) and Stausset al. (2005), if the consumer under goes any purchase or consumption experience, which make him feel dissatisfied and this dissatisfaction is more than he can bear or more than his tolerance level, so it will increase the likelihood of increasing his disappointment and annoyance and consequently it will lead to increase the probability that consumer will complain against this dissatisfaction. Same relation between PExp and $\mathrm{CCBr}$ is already discussed in previous researches, as according to Arndt and Hawes, (2007) dissatisfaction of consumers is a very important variable in determining the CCBr. Reaction or behavior of the consumer really depends on the intensity of good or bad experience, as increased intensity of bad incidents, will lead to react the consumer negatively which may be very hazardous for the company. On the other hand low intensity of badness in experience will lead to change the behavior somewhat positive, and may encourage customer to convey his complaint directly to the company, which is the only 
way through which company can get a chance to improve its product or service and can do its best to retain his customer by rewarding with or compensating his dissatisfaction. So in both cases PExp, either good or bad lead to increase the chances of reacting in some way (Singh and Wilkes, 1996) and also affect the way of presenting their complaint (Martin, 1991).

On the basis of above arguments we can hypothesize that:

\section{H5:- There is a significant relationship between PExp and CCBr.}

Behavioral and attitudinal temperament of a consumer for future situations can be strengthened on the basis of his past experience of complaining. A person is more motivated to complain if his past experience of complaining is good (Singh and Wilkes 1996; Ursic 1985). ATCo can be influenced by PExp. Expectations of a customer raised in complaining if he has a higher prior experience of complaining. If we talk about more past experience it means that the customer acquire more knowledge, communication skills and techniques in the past through related complaining cases which might increase his confidence level as well as positive complaining attitude in making that complain. Furthermore a customer can determine the associated cost and benefit as well as the response of the firm towards their voiced complaint if he has a prior experience. So, it shows that as the positive complaining PExp increases, PPS also increases. According to Ursic (1985) there is a huge difference between the customers who complain more to those who complain less in terms of their belief of higher possibility of success. On the basis of all the above discussion we can hypothesize that:

\section{H6a:- There is a significant relationship between the PE and ATC.}

H6b:- There is a significant relationship between the PE and PPS.

\section{f. Perceived Alienation}

Singh (1989) explain Perceived Alienation (PAl) as the negative image of a dissatisfying firm globally in a customer mind. In addition to it Westbrook (1980) said that Generally PAl can be measured by the degree of unhappiness of a customer. If there is any negative emotion for a firm or its markets than it can be regarded as high PAl. If we look PAl in a broader way than it is the overall feelings of a consumer that the firms as well as its employees are not paying attentions towards them and they have no concern with their satisfaction. More can be the stereotyped attitude of a customer towards the firm if they feel more separated from the firm. Expectations of a customer regarding firm can also be influenced by PAl (Singh and Wilkes, 1996). Furthermore Allison (1978) said that the customers are more likely to have feelings of powerless and helpless when they feel separated from the firm. So, they think that they have a low PPS and this result in negative ATCo.

PAl can be referred as the overall perception about belonging industry of the failing company. Here we can exemplify this as the case of retailing industry. Take the case of retail industry as an example. If a customer believe that the company's retail store and its staff is not showing 
any concern about their need and interest, does not fulfill their commitments and are not honest than it will separate that customer not just from that retail store but also from the overall industry and the customer will have a high PAl. It can be explained as an indicator of the dissatisfaction level of the customer and it means that higher the PAl higher the negative feelings of the customer toward the company or industry as a whole (Westbrook, 1980).

The quality expectation about the product or service of the company product during the exchange can also be affected by PAl (Singh and Wilkes, 1996). When a customer detect a different alienation from the company or industry, he feel helpless and it result in negative attitude when a customer direct complain to a company (Allison, 1978) and hence in this kind of situation the customer feel lower chances of PPS. So we can hypothesize:

\section{H7a: There is a significant relationship between PAI and ATCo.}

\section{H7b: There is a significant relationship between PAl and PPS.}

\section{g. Controllability to complaint}

According to Fishbein and Ajzen (1975) a firm's ability to predict as well as prevent the dissatisfaction level of a customer can be denoted as controllability of dissatisfaction. Perceived behavioral control (PBC) is a construct measuring how an act can be well executed. In folkes's (1984) model if the firm has prevented the problems earlier when a consumer make a complaint and control it very well then the consumer strengthen their complaints. Controllability towards complaint (CTC) can be taken as the locus of responsibility in case of dissatisfaction through which the complaint behavior and attitude of a consumer get affected. Consumer thinks that if the blame can be attributed to firm then there will be a high complaining perceived value to the firm. So consumers increase their positive ATCo when they perceived high controllability. On the basis of above discussion we can hypothesize:

\section{H8: There is a significant relationship between CTC and CCBr.}

We can define CTC as the problem through which a customer got dissatisfied whether and to what extent that problem a company should controlled. This is supported by many past researches that there is a positive influence of CTC on PPS and ATCo. Folkes (1984) said that a consumer's response in making a complaint and/or ask for solving a problem will be intensified if the reason of that problem can be controlled or prevented by the company will be affected by the attribution of failure in a service or a product. If a customer belief that the complaint will bring high PPS and more compensation and the cause of dissatisfaction is the company's precaution failure then the customer is more likely to hold the company responsible. According to Singh (1989) a customer is more likely to complain with more positive attitude when he believes that the company is responsible for the dissatisfaction of the customer. So, we can hypothesize that:

H9a: There exists a significant relationship between CTC and ATC.

H9b: There exists a significant relationship between CTC and PPS. 


\section{1) Macrothink}

\section{Proposed Model of Complaining Behavior:}

Figure 1: Hypothetical Model for the current research

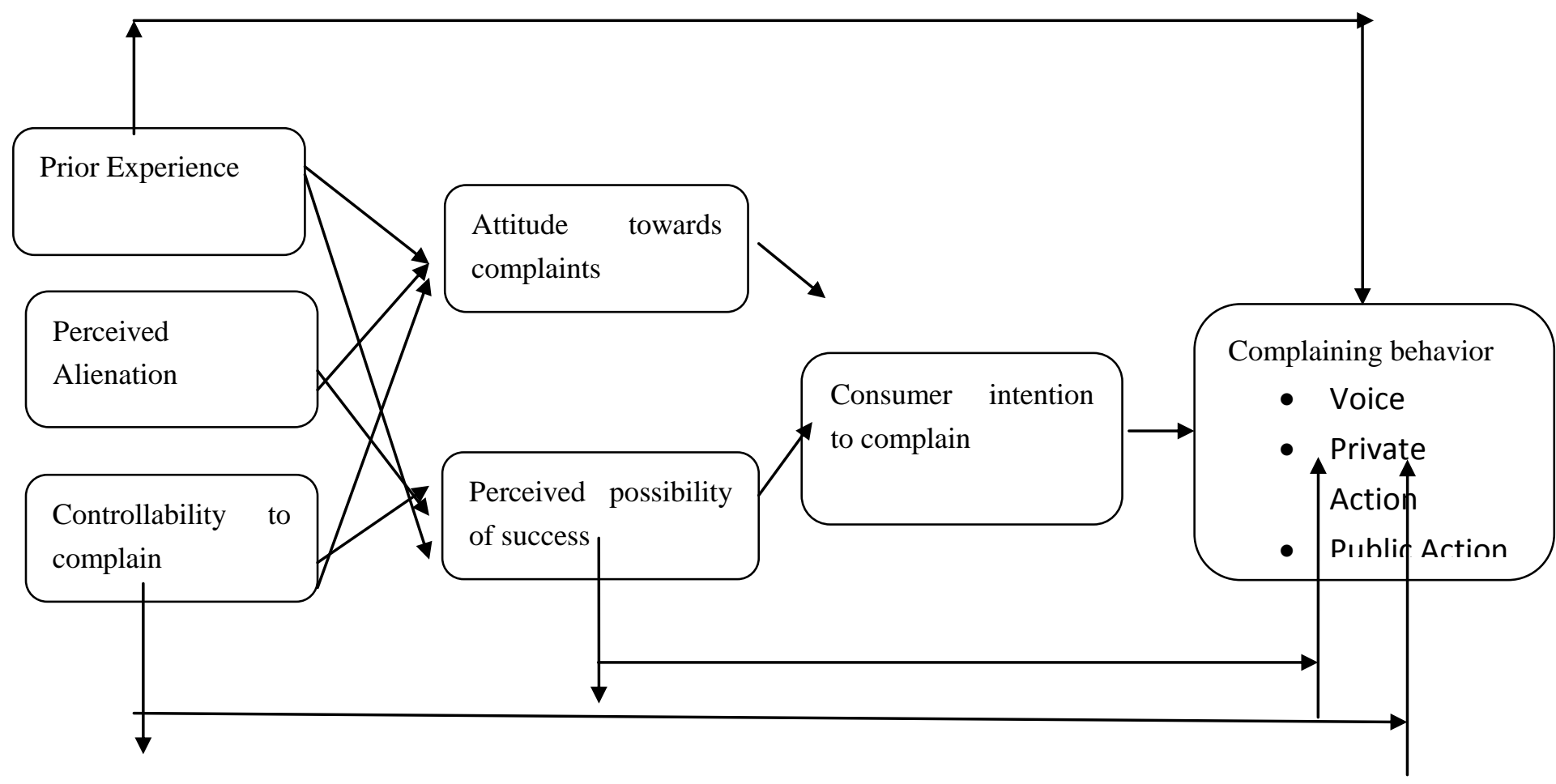

\section{Research methodology:}

This research type is casual. The research that explains the cause and effect relationship among different variables is called casual research. When problem of research is define and clearly identified then the type of research that is conducted is casual research (Zikmund, 1997). It describes the relation of reaction or effect when some action has been done but this is done under some specific conditions when these circumstances are fulfilled then this relationship is explained among different variables. The primary condition is cause comes first then effect occurs and second condition is, there exists a logical relationship among variables.

The main objective of this research is explaining the relationship among different variables and the effect of these variables on dependent variables and also explores the reasons of these relations.

\section{Sample of data:}

To conduct this research gather data from different customers to understand the factors which affect the ITCo and CCBr. This survey was done in May, 2013 and self administered questionnaire was made to collect data from respondents.

Selected common consumers as a population of this research which buying different products in daily life. Primary objective of this research is gathered response of consumers which have 
buying experience. Collect data from consumers by using convenience sampling method technique. In convenience sampling sample is consist of easily available respondent which become the population of this research study.

Self administered questioners are used to collect response of customers. In this survey 200 customers were participate in which 171 questioners were returned that means response rate in this study is $85.5 \%$.

In this research to increase the level of confidence sufficient sample size is used that response represent the response of whole population and use $95 \%$ level of confidence which means that there is only $5 \%$ chances of error occur if the results repeated more than one time. In different surveys $95 \%$ level of confidence is acceptable to rely on results (Niles, 2006).

\subsection{Instrument and Measures}

Questionnaire is the survey instrument in this research which is used to study different variables by the use of different items. One variable has many items that are used to understand the consistency among the response of respondents and it also measure that how respondent response to different items of same variable.

There are two portion of the questioner. One is gather personal information of the respondent that is age, income, status, salary, and education. Second is designed to collect information about different variables that finally has impact on the main variable that is $\mathrm{CCBr}$. CCBr has many items that measure the $\mathrm{CCBr}$ itself. This research used the data of past researches and questioner that is used in it also used in past researches that consist of same items to measure same variable.

The main variable of this research is $\mathrm{CCBr}$ which is measured through four different items and also used other variable to check the impact of these variables on the main variable. Other variable is ITC that has direct effect on $\mathrm{CCBr}$. $\mathrm{CCBr}$ has three items which are used to measure it. ATCo and PPS are the other variables which influence the ITCo. PAl of the company, PExp and CTC act as antecedents that affect the ITCo and PPS are measured through three or more than three items. Likert scale is used to measures the response of all variables that are used in this questioner. This scale has values from 1 to 5 in which 1 show the response of strongly agree, 2 show agree, 3 show neutral response, 4 indicate disagree response and 5 represent strongly disagree response of the respondent.

Scale used in this research to measure the different variables taken from last published researches. Items used in this research are given below:

Table 1: Scales of the Study

\section{Complaining Behavior}

1. I didn't find embarrassing to complain.

2. Complaining about an unsatisfactory product is my duty. 
3. The more frequently I have to use the product the more likely I am to complained if it is faulty.

4. Firms are usually willing to provide repairs for faulty products.

\section{Complaint Intention}

1. I do not easily forget the unpleasant problems without complaining or protesting.

2. I absolutely complain on site (or in the next visit) to the staff or managers.

3. I absolutely ask for problems solving on site (or in the next visit).

Singh's (1989)

\section{Attitude towards complaint}

1. I feel uncomfortable, if not complain directly about dissatisfactory product or service to the company.

2. I feel obliged to complain directly about dissatisfactory product or service to the company.

3. People should complain that much for it happens.

4. It is necessary to ask for change or return, if the product or service does not work well.

5. Normally, I am not reluctant to present a complaint even if the product I have purchased is not good or faulty.

6. In general, I am more likely to complain, ask for refund or to change the product than other people I know.

Blodgett et al. (1993)

\section{Prior Experience}

1. I usually complain to a retail store in the last six months?

2. I usually complained directly a lot to the company?

3. I usually complain many times directly to the company so far.

Blodgett et al. (1993) 


\section{Al Macrothink}

Journal of Public Administration and Governance

ISSN 2161-7104

2013, Vol. 3, No. 3

\section{Perceived Possibility of Success}

1. If you complain directly to the company, they will actually respond properly to your problem.

2. If you complain directly to the company, they will actually respond satisfactorily.

3. If you complain directly to the company, they will actually prevent it from reoccurring.

4. If you complaint about your dissatisfaction to company, they will take appropriate action and provide the better services in future.

5. If you complaint about your dissatisfaction to company, they will provide the better services in future and this will also benefit other consumers.

Richins' (1980)

\section{Controllability of Complain}

1. The problem could have been prevented if I complain.

2. The problem would not happen if the store had been more precautious.

3. Strictly speaking, I was partly responsible if not complain.

Blodgett et al. (1993)

\section{Perceived Alienation}

1. Most of the companies are indifferent to customers.

2. Most of the companies lack the awareness to protect the customer's right and awareness.

3. I think consumers cannot influence company's product management.

4. I think most of the companies are not honest to their customers.

5. I think customers are not important for most of the companies.

6. I think most of the companies forget about their customers after selling their product.

Allison (1978) 


\subsection{Procedure}

Among 200 respondents questioners were distributed in Bahawalpur city. Selection criteria for the respondent is already explain. Purpose and objective of the study is explained to the respondent before giving them the questioners to fill them so they can easily fill the questioners and their response is accurate. 175 questioners were returned and they are all used in study because there is no incomplete questioner.

Using the data of completed questioners, coded them and for further analysis entered these coded questioners into the SPSS sheet.

\subsection{Reliability Analysis}

According to Nunnally (1970) 0.50 is acceptable value of Cronbach's alpha and according to Moss et al. (1998) it is 0.60 . It means that in the questioner of this research all 30 items are reliable and valid that measures the consumer complaining behavior.

Table 2:Reliability of Measurements Instrument

\begin{tabular}{|l|l|l|}
\hline Scales & Items & Cronbach Alpha \\
\hline Complaining behavior & 4 & 0.517 \\
\hline Intention to complain & 3 & 0.545 \\
\hline Perceived possibility of success & 5 & 0.801 \\
\hline Attitude towards complaint & 6 & 0.580 \\
\hline Prior experience & 3 & 0.756 \\
\hline Controllability to complain & 3 & 0.529 \\
\hline Perceived alienation & 6 & 0.770 \\
\hline
\end{tabular}

\section{Hypotheses Testing}

\subsection{Profile of the Respondents}

Demographic and personal information of the respondent like age, gender, income, status and education level is shown in the given table (Table 3 ).

Table 3:Profile of the Respondents 


\begin{tabular}{|c|c|c|c|}
\hline & Category & Frequency & Percentage \\
\hline \multicolumn{4}{|l|}{ Variables } \\
\hline \multirow{2}{*}{ Gender } & Male & 101 & 59.1 \\
\hline & Female & 70 & 40.9 \\
\hline \multirow{6}{*}{ Age } & 15-20 Years & 23 & 13.5 \\
\hline & 20-25 Years & 94 & 55.0 \\
\hline & 25-30 Years & 26 & 15.2 \\
\hline & 30-35 Years & 12 & 7.0 \\
\hline & 35-40 Years & 7 & 4.1 \\
\hline & Above 40 Years & 9 & 5.3 \\
\hline \multirow{6}{*}{ Income } & Below 15000 & 82 & 48.0 \\
\hline & $15000-25000$ & 31 & 18.1 \\
\hline & $25000-35000$ & 16 & 9.4 \\
\hline & $35000-45000$ & 14 & 8.2 \\
\hline & $45000-55000$ & 11 & 6.4 \\
\hline & Above 55000 & 17 & 9.9 \\
\hline \multirow{5}{*}{ Education } & Matriculation & 4 & 2.3 \\
\hline & Inter & 13 & 7.6 \\
\hline & Bachelor & 63 & 36.8 \\
\hline & Master & 65 & 38.0 \\
\hline & MS / M. Phil & 25 & 14.6 \\
\hline
\end{tabular}




\begin{tabular}{|l|l|l|l|}
\hline & PHD & 1 & .6 \\
\hline \multirow{5}{*}{ Status } & Student & 110 & 64.3 \\
\cline { 2 - 5 } & Employed & 43 & 25.1 \\
\cline { 2 - 5 } & Businessman & 10 & 5.8 \\
\cline { 2 - 5 } & Unemployed & 2 & 1.2 \\
\cline { 2 - 5 } & Housewife & 6 & 3.5 \\
\hline
\end{tabular}

\subsection{Hypothesis testing:}

\subsubsection{Complaining behaviour and Intention to complain:}

Significant relationship between ITCo and $\mathrm{CCBr}$ has been approved by the results of this study which is $(\beta=0.253)$ and $(p<0.01)$ that shows relationship is positive and more than $25 \%$ in $\mathrm{CCBr}$ is due to ITCo. This result accepts the hypothesis H1.

\subsubsection{Possibilities of success, Attitude towards complain and intention to complain:}

Study verifies that there is significant positive relationship of both variables PPS and ATCo with ITCo. The relationship of PPS with ITCo has values $(\beta=0.495)$ and $(p<0.001)$. It means that more than $49 \%$ is contributed by PPS in ITCo. Results of regression analysis between ATCo and ITCo are $(\beta=0.134)$ and $(p<0.05)$ which indicate that ATCo contribute more than $13 \%$ to ITCo. These results confirmed the two hypothesis of this study which is H2 and H4.

\subsubsection{Prior experience, Controllability to complain, Attitude towards complain and} Consumer Complaining behaviour:

ATCo and CCBr has positive significant relationship according to this study with $(\beta=0.253)$ and $(\mathrm{p}<0.01)$. This result confirmed hypothesis H3. Results of regression analysis show that there is no relationship exists between PExp and CCBr. The values of the results are $(\beta=-052$.) and $(\mathrm{p}>0.05)$ which are not acceptable so on that basis $\mathrm{H} 5$ was rejected. Regression analysis shows that relationship between PPS and CCBr has insignificant with values $(\beta=0.051)$ and $(\mathrm{p}>0.05)$. So H8 is also not accepted on the basis of this result. 


\subsubsection{Prior experience, Controllability to complain, Perceived alienation and Attitude towards complain:}

While considering the significance between PExp and ATCo, the results of the current study shows no significant relationship between these two variables with $(\beta=0.122)$ and $(p>0.05)$.

According to the results, there is no significant relationship between PAl and ATCo with $(\beta=0.096)$ and $(p>0.05)$. Based on these results, we reject H6a and $\mathrm{H} 7 \mathrm{a}$, and conclude that the study did not find significant relationship of ATCo with PExp and PAl. The regression analysis of study shows that there is a positive significant relationship between CTC and ATCo with $(\beta=0.333)$ and $(p<0.001)$. It means that the CTC contribute almost $33 \%$ to ATCo. So the results support $\mathrm{H} 9 \mathrm{a}$.

By considering the level of significance there is no significant relationship between PAl and ATCo with values $(\beta=0.096)$ and $(p>0.05)$. According to that result H6a and H7a are not accepted. CTCo and ATCo has significant positive relationship on the basis of the results of the study which are $(\beta=0.333)$ and $(p<0.001)$. Results confirmed H9a. This means CTC contributes approximately $33 \%$ to ATCo.

\subsubsection{Prior experience, Controllability to complain, Perceived alienation and Perceived possibility of success:}

On the basis of the results of regression analysis which are $(\beta=0.171)$ and $(p<0.05)$ shows that there is positive significant relationship between PExp and PPS. Results indicate that more than $17 \%$ contribution in PPS is due to PExp. $(\beta=0.134)$ and $(p<0.05)$ are the values of regression analysis between CTC and PPS which explain the positive significant relationship between them. It means more than $13 \%$ contribution in PPS is due to CTC. Results of regression analysis confirmed that there is significant relationship between PAl and PPS but nature of the relation is negative with values $(\beta=-0.172)$ and $(p<0.05)$. These results indicate that PAl contribute more than $17 \%$ to PPS. This study's results accept H6b, H7b and H9b hypothesis.

Table 4: Regression Results

\begin{tabular}{|l|l|l|l|l|l|l|}
\hline Hypothesis & $\begin{array}{l}\text { Model } \\
\text { Variables }\end{array}$ & Estimate & S.E. & C.R. & P & Results \\
\hline H1 & $\begin{array}{l}\text { CCBr } \\
\text { ITCo }\end{array}$ & 0.253 & .069 & 3.024 & $* *$ & Supported \\
\hline H2 & $\begin{array}{l}\text { ITCo } \\
\text { ATCo }\end{array}$ & 0.495 & 0.081 & 7.478 & $* * *$ & Supported \\
\hline H3 & $\begin{array}{l}\text { CCBr } \\
\text { ATCo }\end{array}$ & 0.253 & 0.086 & 2.982 & $* *$ & Supported \\
\hline
\end{tabular}




\begin{tabular}{|l|l|l|l|l|l|l|}
\hline H4 & $\begin{array}{l}\text { ITCo } \\
\text { PPS }\end{array}$ & 0.134 & 0.061 & 2.022 & $*$ & Supported \\
\hline H5 & $\begin{array}{l}\text { CCBr } \\
\text { PExp }\end{array}$ & -0.052 & 0.046 & -0.696 & 0.488 & Not supported \\
\hline H6a & $\begin{array}{l}\text { ATCo } \\
\text { PExp }\end{array}$ & 0.122 & 0.047 & 1.570 & 0.118 & Not supported \\
\hline H6b & $\begin{array}{l}\text { PPS } \\
\text { PExp }\end{array}$ & 0.171 & 0.067 & 2.055 & $*$ & Supported \\
\hline H7a & $\begin{array}{l}\text { ATCo } \\
\text { PAl }\end{array}$ & 0.096 & 0.052 & 1.272 & 0.205 & Not supported \\
\hline H7b & $\begin{array}{l}\text { PPS } \\
\text { PAl }\end{array}$ & -0.172 & 0.074 & -2.128 & $*$ & Supported \\
\hline H9b & $\begin{array}{l}\text { CCB } \longleftarrow \\
\text { CTC }\end{array}$ & 0.051 & 0.066 & 0.663 & 0.508 & Not supported \\
\hline ATC & 0.333 & 0.062 & 4.578 & $* * *$ & Supported \\
\hline
\end{tabular}


Figure 2: Structural Model Results

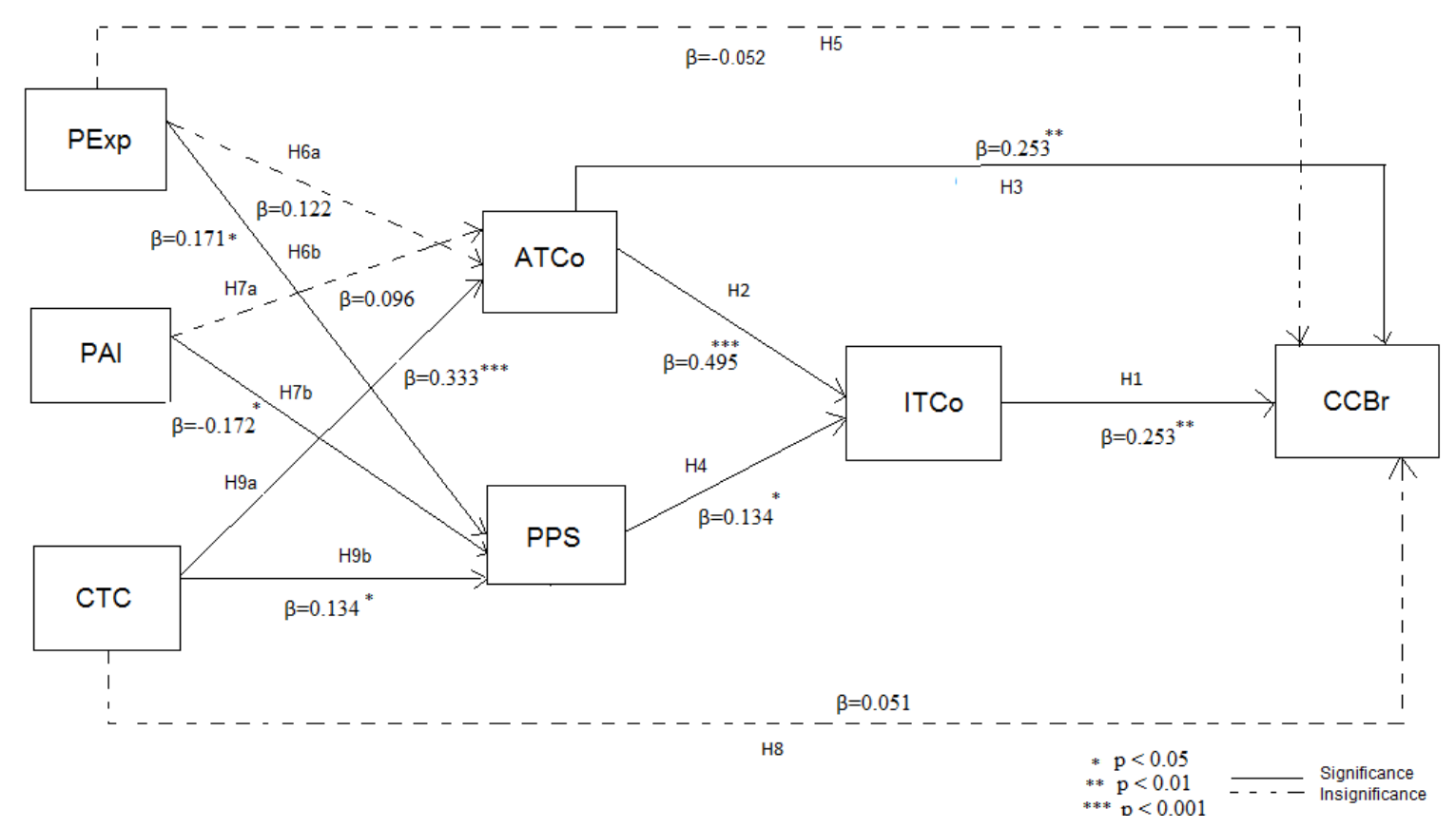

\section{Discussion:}

The objective of this research is to study the impact of attitudinal and perceptual variables on intention to complain and how this intention to complain affects the complaining behavior and also discuss the three main antecedents which are influencing the A\&P variables. The hypothesized relationships were empirically tested and results confirmed that intention to complain and complaining behavior have a significant positive relationship. The change in intention to complain bring a positive change in complaining behavior that can be form of voice, public or private action. Results also confirmed that both attitudinal and perceptual variables have a positive significant relationship with intention to complain (ITCo). As perceptual variable is perceived possibility of success (PPS) and any increase in PPS will tend to increase the ITCo, which means that as consumer think that his complain will be welcomed and resolved by the particular company, there are more chances that he will intend to convey his problem to the relevant company. And attitudinal variable that is attitude towards complain (ATCo) and results also confirmed that an increase in ATCo will tend to increase the ITCo. This is the most crucial part of our study. And most importantly PPS contribute $49 \%$ in ITCo. An important point to discuss here is that both ATC and PPS showed a positive significant relationship with consumer complain intention in some previous studies as well. As Singh and wilkes (1996) proved the same positive significant relationship by studying the ITCo as dependent variable and both ATCo and PPS as independent variable. The results of our studies are also supported by the same results of proven positive significant relationship between the same variables in studies by Chulmin Kim et al, (2003).

Further our research focuses on three major antecedents which directly affect A\&P variables. These attitudinal and perceptual variables play a mediating role when we talk about the 
relationship between three generalized personal variables and ITCo.

PExp as an antecedent has a significant as well as positive impact on PPS, and this relationship is also proven by previous studies by LiYin Jin, (2010), Chulmin Kim et al, (2003), while its impact on ATCo is insignificant which is shown by the results of our study. The former significant relation in fact explains that consumers who have higher experience of complaining and have a knowhow of the procedure of complaining, their perception about having a success full complaint increase in positive manner. But the later relationship shows that any previous experience whether success full or unsuccessful, doesn't have any impact on their perception of making success full complain. As another antecedent, perceived alienation (PAl) and its impact on both the ATCo and PPS was studied in our studies. As results supported this hypothesized relationship, that PAl has a significant relationship with PPS but this relationship is negative in nature, which means that with increased perceived alienation of industry PPS becomes low. Simply it means that as if consumers will never build up negative attitude about the company, if the firm has already negative perception of not giving attention to consumer complaints. And these results are really consistent with the study of LiYin Jin, (2010), Chulmin Kim et al, (2003), which in fact studied and explained the same relationship and results of our study are consistent with these studies. But the relationship of PAl as independent variable on ATCo as dependent variable is insignificant, which means that any type of perception which make consumers alienated from that particular company or industry, doesn't make any impact on attitude of that particular consumer. Controllability to complaint (CTC) was studied as third antecedent in this study, and their impact on PPS and ATCo was studied, and the results of analysis showed that there is a significant relationship between these variables, which means that with the increase in CTC, there must be an increase in ATCo and PPS. Which demonstrates that as consumer more strongly perceive that they themselves can success fully convey and control the process of complaint, it will automatically tend to increase their perception that their complaint will be listened and they will get proper reply or compensation for it, and automatically positive attitude about conveying their problem will be developed.

Another important relationship in which $\mathrm{CCBr}$ was studied as dependent variable and impact of ATCo was studied on it. Results of the study supported that relationship, which demonstrated that with positive change in ATCo will have a positive and significant effect on $\mathrm{CCBr}$.

\section{Limitations and Recommendations:}

This research has many limitations. First is it is conducted in territory of The Islamia University of Bahawalpur and data is collected from students, teachers and some employees so it results can be vary if it is conducted in other universities or services sector like hotel management. Second limitation is that the sample size in this study is small so this decreases the generalize ability of the research. Third is number of variables or factors that is discussed in this study and measure the effect of these variables on $\mathrm{CCBr}$ are limited. There are many factors that can be discussed in this field of research like level of dissatisfaction, word of 
mouth, nationality, gender, salary etc. so these variables can be discussed in the future study. If it is conducted in other fields then it may be possible that rejected hypothesis of this study can be accept in future study. Another limitation is the scenario in which this research has been conduct. The results of different variables on $\mathrm{CCBr}$ may be different when customers face these problems in their real life.

In this research paper data is collected form common consumers but in future this research can be conducted in specific industry like mobile companies or hotel industry can use this research to get benefits from complaints and convert their dissatisfied customers into satisfied customers and bring improvements in their services or products. In today's life complaining behavior considered as most important factor so this study is helpful for the managers of the hotel and tourism industry or other service industries.

\section{Managerial Implications:}

This research may be applied to almost all sectors. Management and staff should impress customers (in attitude, word and deed) that the company will view, welcome and response their complaint as a chance to improve customer service. They should also struggle for efficient solution of complaints so that they can motivate their customers to complain directly to the organization. The company should try to reduce the customer's alienation perception by showing that the company really cares about them, their rights as well as their benefits through a promise that they will work honestly and ethically with the help of public relations and advertising not only establish customer satisfaction-oriented marketing policies. If managers provide their customers various complaining channels and enhance the controllability they can heighten their perceived possibility of success. Attitude towards complaint cannot be built quickly so the firm should change their corporate culture over time, motivate employees so that they can facilitate customer's expression of complaint and increase their willingness to listen to customers.

\section{References:}

1. Ajzen, I. (1991), "The theory of planned behavior", Organizational Behavior and Human Decision Processes, Vol. 50 No. 2, pp. 179-211

2. Allison, N.K. (1978), "A psychometric development of a test for consumer alienation from the marketplace”, Journal of Marketing Research, Vol. 15, pp. 565-75.

3. An Introduction to Theory and Research. Addison-Wesley, MA Folkes, V.S. (1984), "Consumer reactions to product failure: an attributional approach", Journal of Consumer Research, Vol. 10, pp. 398-409.

4. Bearden,W.O. and Oliver, R.L. (1985), “The role of public and private complaining in satisfaction with problem resolution", Journal of Consumer Affairs, Vol. 19 No. 2, pp. 222-40. 


\section{Macrothink}

Journal of Public Administration and Governance ISSN 2161-7104 2013, Vol. 3, No. 3

5. Best, A. and Andreasen, A.R. (1977), "Consumer response to unsatisfactory purchases: a survey of perceiving defects, voicing complaints, and obtaining redress", Law \& Society, Vol. 11, pp. 701-42.

6. Blodgett, J.G., Granbois, D.H. and Walters, R.G. (1993), "The effects of perceived justice on complainants' negative word-of-mouth behavior and repatronage intentions", Journal of Retailing, Vol. 69 No. 4, pp. 399-428.

7. Broadbridge, A. and Marshall, J. (1995), "Consumer complaint behaviour: the case of electrical goods", International Journal of Retail \& Distribution Management, Vol. 23 No. 9, pp. 8-18.

8. Crie, D. (2003), “Consumer's complaint behaviour. Taxonomy, typology and determinants: towards a unified ontology", Journal of Database Marketing and Customer Strategy Management, Vol. 11 No. 1, pp. 60-66.

9. Davidow and Dacin. (1997) "understanding an influencing consumer complaint behavior: improving organizational complaint management," advances in consumer research, Vol. 24, pp. 450-456.

10. Day RL, Grabicke K, Schaetzle T, Staubach F (1981). The hidden agenda of consumer complaining. J. Retail., 57 (3): 86-106.

11. Fishbein, M., Ajzen, I., 1975. Belief, Attitude, Intention, and Behavior.

12. Fornell C,Wernerfelt B. Defensive marketing strategy by customer complaint management: a theoretical analysis. Journal of Marketing Research 1987;24:337-46. (November).

13. Garrett, D.E. and Meyers, R.A. (1996), "Verbal communication between complaining consumers and company service representatives", The Journal of Consumer Affairs, Vol. 30 No. 2, pp. 444-75.

14. Gursoy D, McCleary KW, Lepsito LR (2003). Segmenting restaurant customers based on their complaining response styles. J. Foodserv. Bus. Res., 6(1): 325-375

15. Hart, C. W. L., James, L. H., \& Earl, W. S., Jr. (1990). The profitable art of service recovery. Harvard Business Review, 68, 148-156

16. Hart CWL, Heskett JL, Sasser WE. The profitable art of service recovery. Harvard Business Review 1990;68:148-56. (July/August).

17. Heung VCS, Lam T (2003). Customer complaint behaviour towards hotel restaurant services. Int. J. Contemp. Hosp. Manage., 15(5): 283-289.

18. Hirschman AO. Exit, voice and loyalty: responses to decline in firms, organizations and states. Cambridge, MA: Harvard University Press; 1970.

19. Hoffman, K. D., \& Chung, G. B. (1999). Hospitality recovery strategies: customer preference versus firm use. Journal of Hospitality and Tourism Research, 23(1), 
$71-84$.

20. Huang, J. H., Huang, C. T., \& Wu, S. (1996). National character and response to unsatisfactory hotel service. International Journal of Hospitality Management, 15(3), 229-243.

21. Hupperts, J.W. (2003), “An effort model of first-stage complaining behavior”, Journal of Consumer Satisfaction, Dissatisfaction, and Complaining Behavior, Vol. 16, pp. 132-44.

22. Jacoby, J. and Jaccard, J.J. (1981), "The sources, meaning, and validity of consumer complaint behavior: a psychological analysis”, Journal of Retailing, Vol. 57 No. 3, pp. 4-24.

23. Keng, K.A., Richmond, D., and Han, S. (1995), "Determinants of consumer complaint behaviour: a study of Singapore consumers", Journal of International Consumer Marketing, Vol. 8 No. 2, pp. 59-76

24. Kim, C., Kim, S., Im, S. and Shin, C. (2003), "The effect of attitude and perception on consumer complaint intentions", Journal of Consumer Marketing, Vol. 20 Nos 4/5, pp. 352-71.

25. Martin, N.I. (1991), "Expert-novice differences in complain scripts", Advances in Consumer Research, Vol. 18, pp. 225-31

26. Mattila, S. A. (2001). The effectiveness of service recovery in a multiindustry setting. Journal of Services Marketing, 15(7), 583-596.

27. Prim, I and B. Pras. (1999). "Friendly Complaining Behaviors: Toward a Relational Approach", Journal of Market Focused Management, vol. 3, p.336.

28. Richins, M.L. (1987), “A multivariate analysis of responses to dissatisfaction", Journal of the Academy of Marketing Science, Vol. 15 No. 3, pp. 24-31.

29. Richins, M.L. (1980), “Consumer perceptions of costs and benefits associated with complaining”, in Hunt, H.K. and Day, R.L. (Eds), Refining Concepts and Measures of Consumer Satisfaction and Complaining Behavior, Indiana University Press, Bloomington, IN.

30. Rizwan, M., Ali, S. H., Akhter, S., Abbas, Y., Kanwal, A., Iqbal, S. \& Aziz, W. (2013) Determinants Affecting Consumer Complaining Behavior: A study in a University of Pakistan, Asian Journal of Empirical Research, 3(2), 160-174

31. Rizwan, M., Khan, A., Saeed, I., Shah, K., Azhar, N. \& Anam, W. (2013) Determinants of Customer Complaining Behavior, International Journal of Research in Computer Applications and Management, 3(3), 119-124

32. Singh, J. (1988). Consumer complaint intentions and behaviour: definitional and taxonomical issues. Journal of Marketing, 52, 93-107. 
33. Singh, J., Widing, R. E. (1991). What occurs once consumers complain? A theoretical model for understanding satisfaction/dissatisfaction outcomes of complaint responses. European Journal of Marketing, 25(5).

34. Singh, J. and Wilkes, R.E. (1996), "When consumers complain: a path analysis of the key antecedents of consumer complaint response estimates", Journal of the Academy of Marketing Science, Vol. 24 No. 4, pp. 350-65.

35. Singh, J. (1990), "Voice, exit and negative word-of-mouth behaviours: an investigation across three service categories", Journal of Academy of Marketing Sciences, Vol. 18 No. 1, pp. 1-15.

36. Singh, J. (1989), “Determinants of consumers' decisions to seek third party redress: an empirical study of dissatisfied patients", Journal of Consumer Affairs, Vol. 23, pp. 329-63.

37. Tronvoll, B. (2007), "Complainer characteristics when exit is closed", International Journal of Service Industry Management, Vol. 18 No. 1, pp. 25-51.

38. Ursic, M. (1985a), “Consumer use of the legal redress system”. Southern Marketing Association Proceedings, pp. 273-5

39. Ursic, M. (1985b), “A Model of the consumer decision to seek legal redress". Journal of consumer Affairs, Vol. 19, pp. 20-35

40. Westbrook, R.A. (1980), "Intra-personal affective influences on consumer satisfaction with product", Journal of Consumer Research, Vol. 7, pp. 49-54

41. Yang TC (2005). The development of an effective recovery programme after service failures: a case study of restaurants in Glasgow. Tour. Hosp. Plan. Dev., 2(1): 39-54. 